\title{
Campanha da Legalidade, Luta de Classes e Golpe de Estado no Rio Grande do Sul (1961-1964) ${ }^{1}$
}

Diorge Alceno Konrad* e Rafael Fantinel Lameira**

Resumo. O processo histórico de construção do Golpe Civil-Militar, vitorioso em 1964, teve na Campanha da Legalidade um momento singular. O ano de 1964 foi antecedido por uma profunda polarização política entre os setores conservadores e progressistas. Foi no Rio Grande do Sul que iniciou a resistência das forças constitucionais à tentativa de golpe, em 1961. Esta primeira tentativa golpista foi frustrada pela mobilização popular, dirigida a partir de Porto Alegre. Situação que não se repetiu em 1964, quando a resistência para a Legalidade teve nova tentativa. Entender este processo em uma dimensão mais ampla e complexa da luta de classes é o objetivo deste artigo.

Palavras-chave: Brasil. Campanha da Legalidade. Golpe Civil-Militar de 1964. Luta de Classes. Rio Grande do Sul.

* Professor Adjunto do Departamento e do Programa de Pós-Graduação em História da UFSM, Doutor em História Social do Trabalho pela UNICAMP. Endereço Eletrônico: gdkonrad@uol.com.br

** Mestrando do Programa de Pós-Graduação em História da UFRGS, Graduado em História - Licenciatura Plena e Bacharelado pela UFSM, Ex-Bolsista de Iniciação Científica Probic/FAPERGS. Endereço Eletrônico: rflameira@gmail.com 
Campanha da Legalidade, Luta de Classes e Golpe de Estado...

Em meados da década de 1950, a radicalização política entre distintos projetos de sociedade foi se tornando mais clara, especialmente depois da tentativa de Golpe Civil-Militar, abortado pelo suicídio do Presidente Getúlio Vargas, em 1954. Sucessivas crises políticas e tentativas golpistas foram sendo postas em marcha pelos setores liberais e conservadores da sociedade brasileira. A mais marcante foi desencadeada pela renúncia de Jânio Quadros, abrindo uma crise institucional em que as forças progressistas e de esquerda impediram o golpe dos ministros militares, garantindo a posse do Vice-Presidente João Goulart, abrindo um contexto diferente na política brasileira.

Reconstituindo os conflitos sociais e políticos que marcaram o processo de polarização política e as ações concretas dos sujeitos históricos que a construíram, resgatado o processo de luta de classes e de projetos políticos que culminaram no Golpe Civil-Militar de 1964, desfechado pelos setores conservadores da sociedade, a fim de suprimir os conflitos sociais, barrar a radicalização democrática e pôr termo aos projetos de reformas sociais defendidos pelos movimentos progressistas e de esquerda, chega-se a outra dimensão daquele contexto.

A chamada Guerra Fria e as disputas político-ideológicas que opõem ao projeto capitalista e liberal o projeto socialista no contexto de radicalização política aberta após a Segunda Guerra Mundial, bem como, no plano regional, a Revolução Cubana de 1959, devem ser levados em conta. Para a devida compreensão do Golpe CivilMilitar, perpetrado pela direita brasileira, em 1964, deve-se prestar atenção à radicalização política na década de 1960.

Foi naquele contexto que Jânio Quadros tomou posse na Presidência da República, apresentando seu programa que tentava conciliar, de forma ambígua, medidas liberais em termos de política econômica, com ações de fundo nacionalista, como uma política externa independente acompanhada da defesa de reformas sociais.

Eleito pelo Partido Democrata Cristão (PDC), inexpressivo em nível nacional, mas com apoio da União Democrática Nacional (UDN). No Rio Grande do Sul, Jânio teve o apoio de grande parte do Partido Social Democrático (PSD) e do Partido Libertador (PL), além de uma dissidência do Partido Trabalhista Brasileiro (PTB), 
chamado de Movimento Trabalhista Renovador (MTR). Tais partidos, que se denominaram de Frente Democrática, insurgiram-se contra a candidatura do Marechal Henrique Teixeira Lott, visto como incentivador da agitação e cúmplice dos comunistas.

A política ambígua de Jânio tornou sua situação muito delicada. A saída pretendida não obteve êxito. Sua renúncia foi aceita com facilidade. Saindo do Brasil, declarou "[...] um dia voltarei como Getúlio". As forças reacionárias haviam se irritado ainda mais com os avanços de Cuba e com a política independente de Quadros. Os ataques aumentavam e seriam destinados especialmente a todos os setores nacionalistas, progressistas e socialistas. Quando Jânio Quadros renunciou, em agosto de 1961, por exemplo, uma das grandes justificativas dos ministros militares para impedir a sua posse foi o fato de João Goulart promover a agitação nos meios operários, ser vinculado aos comunistas e ser simpático aos países socialistas.

\section{A Reação Democrática com a Campanha da Legalidade}

Em 1961, a tentativa de golpe não foi vencedora porque o Governador do Rio Grande do Sul, Leonel de Moura Brizola, assumiu uma postura radicalmente contra a iniciativa e praticamente tornou o estado uma região rebelada. Imediatamente, ele recebeu apoio de boa parte da sociedade sul-rio-grandense, a grande maioria dos deputados, sindicalistas, estudantes etc., enquanto a Brigada Militar foi posta em prontidão. Em nível nacional, a maioria das forças políticas identificadas com um projeto nacionalista, e mesmo aqueles que somente defendiam a legalidade se opuseram ao golpe, promovido pelos três ministros militares de Jânio, Silvio Heck; da Marinha, Odílio Denys, do Exército e Grun Moss, da Aeronáutica, com a cumplicidade do Presidente interino Ranieri Mazzilli. Quando o comandante do III Exército, general Machado Lopes, aderiu ao movimento liderado por Brizola, a resistência começou a crescer, então contando com o maior contingente militar do Brasil. 
Campanha da Legalidade, Luta de Classes e Golpe de Estado...

O movimento foi vitorioso em função da grande mobilização popular, pela defesa da legalidade constitucional, pela decidida liderança de Leonel Brizola e pela falta de apoio social mais amplo dos setores conservadores. Também pelo decidido apoio militar do III Exército e de oficiais e combatentes desertores das regiões militares fiéis a Odílio Denys, o principal articulador do golpe. O Governador goiano, Mauro Borges, foi o principal aliado do Rio Grande do Sul, enquanto a grande maioria das forças políticas assumiu uma postura moderada. A exceção foi Carlos Lacerda, que apoiou efusivamente o golpe, abrindo uma gigante onda de repressão policial e censura na Guanabara. No Rio Grande do Sul, aqueles que apoiaram o golpe, ou pelo menos que não se opuseram a ele, ficaram em relativo silêncio. Além da Rádio da Legalidade, organizada pelo Governo do estado, principal meio de comunicação entre a resistência, já que os ministros militares censuraram todas as outras formas de fazê-lo, milhares de pessoas se alistaram nos batalhões populares, chamados comitês da resistência democrática, e nas Brigadas da Legalidade.

Logo após a posse de Goulart, em setembro de 1961, entretanto, começaram as mudanças do chamado dispositivo militar do governo. Ao passar o comando da $3^{\text {a }}$ Divisão de Infantaria no Rio Grande do Sul, sediado em Santa Maria, ao General Mourão Filho, o General Peri Bevilacqua ${ }^{2}$ pronunciou um discurso em que afirmava ser necessário suprimir tanto o despotismo sindical quanto o despotismo militar, expressando um pensamento corrente no seio do Exército: o nacionalismo legalista. O que de forma nenhuma significava simpatia pela esquerda, muito menos pelos comunistas, como revelava o General em seu discurso (Correio do Povo, 19 de outubro de 1961).

A resposta conservadora à Legalidade, dada pelo Congresso, foi a aprovação da Emenda Parlamentarista, frustrando a resistência, e inclusive Brizola, que se recusou a ir à posse do Presidente, em Brasília. Um verdadeiro golpe legal. Após a crise, Goulart foi amplamente felicitado pelas forças conservadoras por sua moderação e equilíbrio. Pouco tempo depois, ao revelar sua posição na crise da renúncia, Jango já firmava a sua posição pacífica. Afirmou, em homenagem prestada a ele, em São Borja, que transigiu para não marcar com sangue seu caminho para a presidência (Correio do 
Povo, 7 de novembro de 1961). O primeiro gabinete parlamentarista foi chamado de conciliação nacional, pois contava com membros de todos os partidos, incluindo a UDN. O primeiro ministro era o moderado Tancredo Neves, intermediador junto a Goulart da aprovação do parlamentarismo.

Porém, a mobilização animou a todas as forças identificadas com o nacionalismo e com as reformas sociais, além daqueles que acreditavam na democracia. A percepção geral era de que a democracia no Brasil, embora limitada, já estava consolidada e a sociedade não toleraria mais golpes de Estado. No entanto, a sensação quase geral era de que vitória não havia sido completa, exceto os conservadores, que aplaudiram a saída ordeira e pacífica, colocando o Presidente com poderes limitados.

Entretanto, imediatamente as manifestações passaram a exigir um plebiscito para confirmar o novo sistema de governo, o que foi rechaçado pelos partidos conservadores, pois eles entendiam que a democracia era representativa e os deputados tinham legitimidade para aprovar as mudanças. Ainda por cima, o plebiscito poderia gerar inquietação e agitação, o que seria prejudicial para a ordem.

Superada a crise, o general Machado Lopes e o Governador de Goiás, Mauro Borges, foram declarados cidadãos rio-grandenses, tamanha a popularidade do movimento. Mas a fala de Brizola foi clara: o golpismo apenas hibernou.

A Campanha da Legalidade marcou profundamente a experiência de Brizola e do conjunto das forças nacionalistas. Representou uma virada na postura do Governador do Rio Grande do Sul. A partir de então, suas posições políticas radicalizaram-se e a crença na necessidade das reformas sociais e na defesa de políticas nacionalistas se tornaram ainda mais fortes. Além disso, sua popularidade aumentou expressivamente. Foi declarado cidadão de centenas de cidades brasileiras, incluindo São Paulo e Recife, sendo homenageado por diversas associações nacionais como a Associação Brasileira de Imprensa (ABI) e a Ordem dos Advogados do Brasil (OAB). Uma de suas falas foi esclarecedora, ao ser recebido com grandes festas populares, no Rio de Janeiro, para ser homenageado pela atuação na crise. Afirmou, ao ser perguntado sobre uma possível candidatura a Presidente: 
Campanha da Legalidade, Luta de Classes e Golpe de Estado...

Não faço planos para o futuro, principalmente a longo prazo. Não tendo ilusões quanto ao meu futuro pessoal, porque a convivência com os problemas administrativos vem me conduzindo para uma posição radical, e isso é um grande pecado na carreia de um homem público, dentro dos quadros tradicionais da política brasileira (Correio do Povo, 25 de setembro de 1961).

Mesmo após a crise, a culpa ou a preocupação em geral recaiu principalmente sobre os comunistas. Os militares passaram a defender que os partidários do golpismo favoreceram a estes. A própria resistência ao golpe foi acusada de comunista. O comunismo era a pecha política para todas as acusações políticas contrárias aos interesses conservadores. Pode-se perceber que todos os movimentos sociais e políticos que defendiam reformas sociais, direitos dos trabalhadores ou dos sem-terra, eram acusados de comunistas, agitadores, inimigos da ordem, tudo que aquele adjetivo poderia significar nos quadros da tradicional política brasileira, como referiu Brizola.

\section{Lutas por Reformas Sociais e a Reação Conservadora Durante o Governo Jango}

Dentre os movimentos sociais, no Rio Grande do Sul, destacaram-se os movimentos estudantis, sindical e dos agricultores sem-terra, esses organizavam-se em busca de seus direitos e de participação na política, gerando um receio crescente nos meios conservadores.

Por outro lado, também foi expressivo o grau de coesão e de reconhecimento dos interesses comuns das classes dominantes sulrio-grandenses. ${ }^{3}$ A Federação das Indústrias do Rio Grande do Sul (FIERGS), a Federação das Associações Comerciais (FEDERASUL) e a FARSUL foram os principais protagonistas de uma cultura política marcada pela importância do associativismo na defesa dos interesses de grupo das dominantes. Da mesma forma, setores majoritários do clero da Igreja Católica e parte significativa da oficialidade do Exército tiveram papel político importante. Entretanto, talvez o traço mais marcante da política do Rio Grande do Sul, naquele 
momento, foi a ativa participação e a significativa legitimidade social dos partidos políticos.

Por trás do argumento conservador, o eixo discursivo centravase no anticomunismo. Nas falas dos políticos, em geral, dos membros da Igreja, das classes produtoras, do ruralismo etc., todos viam o perigo vermelho como ameaça a ordem social e política brasileira, a qual, no seu tendimento, seria ordeira, cristã e pacífica. Desta forma, havia nestas representações, de um lado, uma ideologia naturalmente democrática e cristã, de outro, uma exótica, exógena e estranha aos gaúchos, o comunismo ateu.

Carla Rodeghero $(1998)^{4}$ demonstrou como a Igreja Católica associava os comunistas ao mal e a tudo que fosse imoral, principalmente no discurso do Arcebispo de Porto Alegre, Dom Vicente Scherer, o qual gozava de muito respaldo social e político. Para esses setores conservadores, onde havia reivindicações e lutas, eles só viam agitação, baderna, subversão, etc. Este certamente foi uma fator fundamental para o desencadeamento do Golpe de 1964, uma bandeira que conseguiu arregimentar parte hegemônica das classes médias (com medo da proletarização crescente), latifundiários, empresários, setores militares e parte majoritária da Igreja Católica.

O deputado libertador Paulo Brossard, um dos principais líderes dos setores conservadores, em discurso na Assembleia Legislativa, fez um apelo pela "união das forças democráticas contra os movimentos de inspiração totalitárias" que se verificavam no estado e no País. Enunciava o que seria a marca da campanha política que culminaria no Golpe (Correio do Povo, 5 de dezembro de 1961).

No inicio de 1962, em meio a uma onda de atentados terroristas promovidos pelo Movimento Anticomunista (MAC), a sede da União Nacional dos Estudantes (UNE) foi metralhada e a acusação novamente recaiu sob os comunistas. A intolerância contra os comunistas era tamanha que as autoridades eram coniventes com verdadeiros ataques contra a democracia em nome da democracia. ${ }^{5}$ Em junho de 1962, no início da campanha eleitoral, o candidato do PTB, Egydio Michaelsen, repudiava o apoio e os votos do PCB, dizendo-se democrata e anticomunista. Isto se dava num contexto no qual Brizola, líder trabalhista, era cada vez mais atacado por supostamente favorecer a agitação e a subversão. As suspeitas e os 
Campanha da Legalidade, Luta de Classes e Golpe de Estado...

boatos sobre uma nova possível tentativa de golpe de direita, através da bandeira do anticomunismo, começavam a circular de forma mais recorrente. Igualmente, os militares começavam a insistir reiteradamente na necessidade de combate à infiltração comunista no País.

Na campanha de 1962, por exemplo, declarações de Luiz Carlos Prestes favoráveis a ações do Governo do Rio Grande do Sul, e acusações de que o candidato do PTB seguiriam a linha de Brizola e de esquerda, eram usados como antipropaganda, acusação ou comprovação de sua "inconveniência como governador". $\mathrm{Na}$ ocasião, Dom Vicente Scherer, o arcebispo metropolitano de Porto Alegre, veio a público denunciar a "agitação" no País e afirmar que não queria trocar a bandeira auri-verde por uma foice e por um martelo, sugerindo a infiltração comunista nos debates sobre reformas sociais e nas candidaturas a eleição.

As forças identificadas com o nacionalismo estavam muito longe das propostas socialistas, constantemente se opondo a elas. Mas acusações de que eram comunistas foram o cimento ideológico que unificou a diversidade das classes dominantes, a fim de deflagrar a construção do Golpe de 1964. Nesse sentido, a Campanha da Legalidade, vitoriosa em 1961, aprofundaria a reação dos setores conservadores.

A vitória da Legalidade apenas adiou a sanha golpista, sendo, posteriormente, o próprio movimento acusado de se constituir em bases comunistas, o que resultou em ampliação do discurso conservador, mobilizando brasileiros para aderir à defesa do Golpe, como na construção do complexo Instituto Brasileiro de Pesquisas Sociais (IPES)/Instituto Brasileiro de Ação Democrática (IBAD), articulado por setores majoritários do capital, tanto em nível nacional como estrangeiro. $^{6}$

Antes ainda da Legalidade, em fevereiro de 1961, Leonel Brizola, concedeu uma entrevista ao Correio do Povo afirmando que a política de Juscelino Kubitschek havia sido nefasta e predatória ao estado, defendendo a necessidade de reformas sociais a fim de romper o ciclo da pobreza e do subdesenvolvimento. Para Brizola, toda ordem jurídica era ultrapassada quando não servia a justiça social, citando o problema da terra, na qual alguns teriam quilômetros extensivos ou improdutivos enquanto milhares não possuíam 
terra para morar e trabalhar, o que gerava miséria, fome, ódio e revolta. Assim, seria preciso romper com situação em que a Nação se sacrificava para produzir a fim de entregar as riquezas a alguns grupos privilegiados internos ou externos (Correio do Povo, $1^{\circ}$ de fevereiro de 1961).

No dia 10, no auditório da Faculdade de Ciências Econômicas da UFRGS, Brizola proferiu a primeira palestra sobre o processo de marginalização do Rio Grande do Sul. Defendeu os trabalhadores que se esforçavam para se sustentar, mas que não poderiam romper a barreira da pobreza sem a ajuda dos poderes públicos, traçando um paralelo com Cuba, onde para ele a miséria gerou intranquilidade e a Revolução. Reafirmou que o Brasil era uma nação espoliada e era preciso uma transformação estrutural para dinamizar a economia.

Em abril de 1961, Brizola manifestou sua "repulsa" a invasão de Cuba por tropas exiladas e norte-americanas. Segundo o Governador, e muitos outros políticos que se manifestaram sobre o caso, tal medida feria o princípio da autodeterminação dos povos. Em Porto Alegre, entidades sindicais e estudantes realizaram diversas manifestações e um comício no largo da Prefeitura, contra a "agressão ao povo cubano". Os próprios deputados da Frente Parlamentar Nacionalista enviaram um protesto ao Presidente dos Estados Unidos, John Kennedy contra a intervenção daquele país na ilha cubana. Por outro lado, em São Leopoldo, os "estudantes livres" manifestaram-se a favor da invasão e contra os "sanguinários comunistas cubanos Fidel e Guevara”.

Como resposta às ofensivas conservadoras no plano nacional, após a vitória da Legalidade, em 1961, e como tentativa de avançar nas reformas sociais, os nacionalistas organizaram uma frente política. No dia do aniversário de Goiânia, uma das cidades que liderou a resistência ao golpe de 1961, o deputado Souza Nobre, do PTB, leu um manifesto de criação da Frente de Libertação Nacional (FLN), articulada e liderada por Mauro Borges e Leonel Brizola. Nesse manifesto, era dito que as forças golpistas reacionárias continuavam em articulação a fim de barrar as reformas sociais ansiadas pelo povo. Por outro lado, afirmava-se a mobilização popular como apoio ao Congresso e à legalidade legítima, que fizesse as reformas e superasse a desigualdade social. Além disso, esse documento defendia 
a crença na indústria nacional, a crítica ao capital multinacional e a exploração imperialista (Correio do Povo, 25 de outubro de 1961).

Merece destaque, também, o debate sobre a Lei de Remessa de Lucros, aprovada ainda em dezembro de 1961. Alvo de forte oposição das "classes produtoras" e dos políticos tradicionais. A Bolsa caiu vertiginosamente após sua aprovação, enquanto os discursos afirmavam que ela levaria ao caos e à falência do Brasil, sendo péssima para o desenvolvimento do País. Aqueles que a defendiam afirmavam a necessidade de valorizar o capital nacional e o bom capital estrangeiro, como defendia o próprio Presidente. A FLN publicou no Correio do Povo, em 17 de dezembro de 1961, um A pedido, no qual usava frases e posições de Vargas que tentavam legitimar a necessidade dessa lei. A disputa, durante esse mês foi acirrada, sendo que os contrários à lei eram maioria e contavam com mais espaço público para defender suas posições, embora o projeto tenha efetivamente sido aprovado com maioria.

\section{A Reforma Agrária no Centro do Debate Político}

Certamente a Reforma Agrária foi o tema mais controverso em termos dos debates acerca das reformas sociais que seriam chamadas reformas de base. Não é difícil imaginar por que. No caso do Rio Grande do Sul, estado que tem sua formação histórica, tanto econômica quanto política e culturalmente, baseada no latifúndio e na grande propriedade da terra, havia uma classe dominante ruralista muito bem organizada em torno do seu órgão de representação, a FARSUL, entidade modelo e destaque na organização nacional, junto à Confederação Rural Brasileira (CRB). Aliás, a consciência dos interesses comuns tanto dos latifundiários, que se autorreconheciam como ruralistas, quanto das classes dominantes no estado são notáveis. Estes foram setores fundamentais nas campanhas contra os comunistas e seus supostos cúmplices, Leonel Brizola e João Goulart.

Neste ponto contavam com um forte apoio do jornal Correio do Povo, que publicava constantemente entrevistas ou manifestações sobre a reforma agrária, todas com o mesmo sentido de fundo. Opi- 
niões e "estudos" dos próprios ruralistas eram apresentadas como confiáveis, imparciais e legítimas, afirmando que a reforma agrária deveria ser feita com as terras não ocupadas ou de propriedade do estado (Correio do Povo, 6 de dezembro de 1961). Dessa forma, explicitava verdadeira aversão a ideia de divisão dos latifúndios.

Em função dos debates realizados nacionalmente em torno da reforma agrária e da suposta disposição do gabinete parlamentar em realizá-la, o Presidente precisou acalmar os ruralistas, afirmando em reunião com esses que a reforma agrária não poderia ter sentido subversivo ou de agitação. Em virtude desses debates, a FARSUL, já bastante ativa, intensificou suas ações. Além da formação de grupos de estudos sobre reforma agrária, preparou com grande repercussão e antecedência uma concentração rural em Santa Maria. Segundo seu Presidente, Antonio Saint-Pastous de Freitas, a concentração preparatória a VI Conferência Rural Brasileira era justificada, devido à " [...] impossibilidade da classe rural adiar ou ficar alheia às grandes discussões do momento político”.

Como resposta, uma declaração foi publicada como $A$ pedido pelo Movimento dos Agricultores Sem-Terra do Rio Grande do Sul, organizada como associação em 67 municípios do estado. Segundo o próprio movimento, sob o título Apelo ao Congresso de Santa Maria, assinado por Milton Serres Rodrigues:

Por favor senhores grande proprietários reunidos em Santa Maria, se nossos clamores não chegam até vós, ouçam a recomendação da Exa. Revma. D. Vicente Sherer: “os grandes proprietários, proclamamo-lo sem cessar devem conformar-se com a redução dos seus haveres, A disseminação da propriedade é um postulado fundamental de uma ordem social aceitável e justa". (A "Voz do Pastor". 1-11962.) Queremos ser proprietários e não simples agregados ou parceiros. Queremos a nossa própria terra para viver e trabalhar com as nossas famílias. Até agora só cuidamos a terra dos outros e continuamos na miséria e nossos filhos sem futuro. Se todos nós somos cristãos e iguais perante Deus, não é a própria negação do cristianismo, uns com tanta terra e morando nas cidades, e milhares e milhares 
Campanha da Legalidade, Luta de Classes e Golpe de Estado...

de famílias vivendo em ranchos pelos campos ou como marginais, sem ao menos uma pequena propriedade? Viva a reforma agrária! Ela é abençoada por Deus (Correio do povo, 4 de janeiro de 1962).

Este apelo, do ponto de vista das declarações constantes desses setores que afirmavam a necessidade de uma reforma agrária cristã e democrática, soava desconcertante para os grandes proprietários, os quais tinham um aliado em Dom Vicente Scherer. Esta mesma mensagem foi republicada no dia da abertura da concentração rural. Não é preciso mencionar que não foram feitas referências a ela, nem no Congresso nem pelas autoridades. Um estranho, mas simbólico silêncio no ar.

Em 6 de janeiro de 1962, iniciou o Congresso, contando com mais de 1000 convencionais, na Escola Estadual Olavo Bilac, em Santa Maria, delegações de todas as associações rurais do estado, contando com considerável respaldo político da classe e de políticos ligados ao ruralismo. O Encontro, responsável pelas diretrizes da atuação da classe naquela conjuntura política em que as reformas sociais eram amplamente reivindicadas, teve como principal tema, como poderia se imaginar, a Reforma Agrária. As posições políticas foram expressas na carta de princípios divulgada pela FARSUL e nos inúmeros depoimentos e discursos políticos e ações concretas que tomaram corpo no pré-1964. O inusitado é que no encerramento, o orador oficial tentou reafirmar que não representavam "um acampamento de reacionários", completando que desejavam "uma reforma agrária, mas sem emoções, paixões subalternas ou interesses escusos".

Muito significativa foi a proposta aprovada de que se organizasse em âmbito regional e federal um Movimento Ruralista com poderes para influir decisivamente nos resultados das eleições. A tese era de que o ruralismo deveria se organizar como força política a fim de sair da defensiva em que se encontrava e se lançar numa ofensiva enérgica em defesa de seus interesses (Correio do Povo, 10 de janeiro de 1962). Fica claro, portanto, o objetivo do Congresso: organizar e unificar os interesses dos grandes proprietários para combater a legitimidade social das demandas por reformas de base, em especial 
da reforma agrária, coordenar a defesa de seus interesses de classe e intervir como força política.

A carta merece atenção especial do Correio do Povo que, em editorial, manifestou amplo apoio às decisões do Congresso, defendendo que a divisão das terras não poderia ser realizada por preceitos e pressões coletivistas, apenas sob o respeito à propriedade privada. O editorial afirmava ainda que se podia distribuir as terras inaproveitadas e adotada a priorização da colonização das terras que se encontravam no vasto domínio do Estado e da União (Correio do Povo, 11 de janeiro de 1962).

Concomitantemente ao fim da concentração ruralista, teve início um movimento organizado regional de reforma agrária, em Nonoai, quando camponeses organizaram-se para ocupar terras públicas de uma empresa uruguaia, a fim de distribuí-la com o apoio do prefeito local. Segundo o próprio jornal, o clima na cidade era de calma, apoio e satisfação da população local em relação ao movimento e à distribuição de terras.

Dias depois, atendendo os motivos expostos pelo Secretário de Agricultura, aos apelos dos prefeitos de Nonoai, Passo Fundo e Sarandi, além dos próprios membros do movimento reivindicatório, Brizola assinou o ato de desapropriação da área da Fazenda Sarandi, denotando apoio às reformas sociais. De propriedade das Estâncias Julio Mailio, de Montevidéu, com aproximadamente 25 mil hectares, a fazenda foi considerada de utilidade pública (Correio do Povo, 16 de janeiro de 1962).

Esta ação que parecia de grande vontade pública foi, no entanto, seriamente atacada por deputados da oposição, classificada como primária e demagógica, insufladora da agitação rural, enquanto a situação tentava justificar o ato em base social, além do respaldo constitucional. Em nota oficial, a FARSUL veio a público classificando o ato do governo de antidemocrático e se postando contra a desapropriação da área, reafirmando as posições da carta de Santa Maria (Correio do Povo, 18 de janeiro de 1962).

Após a resolução da questão de Sarandi, surgiu outro movimento organizado no estado. Cerca de 1500 camponeses, reivindicando que o estado loteasse e vendesse a eles terras conhecidas como Banhado do Colégio, no município de Camaquã. Tratar-se-ia de 
Campanha da Legalidade, Luta de Classes e Golpe de Estado...

terras de propriedade da União e do estado que, à medida que os governos fossem drenando a área, proprietários próximos iriam se apropriando indevidamente dos espaços. A polícia foi chamada para manter a ordem. Desta vez, os proprietários rurais reagiram mais violentamente, principalmente a Associação Rural do município, acusando o governo de ser conivente com movimento demagógico e chegando ao limite de solicitar tropas do Exército, a fim de manter a ordem local. O grande temor era a forma como o problema estava sendo conduzido, gerando reação intensa nos meios rurais perante a suposta falta de garantias.

Em meio aos debates, o governo foi acusado de já ter planejado previamente a ocupação da fazenda Sarandi. A repercussão foi ampla, sendo que o governo foi alvo de muitas críticas, enquanto que os conflitos refletiram no Rio de Janeiro, onde ocorria a VI Conferência Rural Brasileira, que divulgou uma nota criticando a postura do Governo do estado e a falta de garantias à propriedade. O encontro afirmou, também, a necessidade de uma reforma agrária democrática, cristã e técnica.

Em meio aos conflitos, através de um decreto de 29 de janeiro, o Governador regulamentou a reforma agrária no Rio Grande do Sul, estabelecendo tributação especial ou desapropriação para terras improdutivas e a organização de planos de colonização e organização de fazendas coletivas nas terras distribuídas aos camponeses (Correio do Povo, janeiro de 1962). Um dia depois, o estado declarou de urgência a distribuição de 19 hectares de terras drenadas pelo governo na área do Banhado.

Das críticas, a oposição passou a acusações. Daniel Krieger, senador gaúcho (UDN), e Aliomar Baleeiro, deputado da UDN, declararam que o governador era um agitador que incentivava as invasões de terras e formularam uma denúncia vaga de uma suposta tentativa de apropriação da fazenda Sarandi. A tensão era tanta que Brizola foi chamado a Brasillia por Goulart. O presidente da FARSUL partiu para a acusação, afirmando que a Reforma Agrária era apenas cortina de fumaça para desencadear a perigosa agitação subversiva no País. O PSD divulgou nota criticando o governo e a agitação rural, traduzida sob a ideia de intranquilidade dos proprietários. Enquanto isso, novos movimentos de menor expressão surgiam no estado em Tapuã, Itaqui e Alegrete. 
A tensão aumentou, enquanto os ruralistas convocaram uma assembleia da FARSUL a fim de debater as questões, condenando a política do governador gaúcho. Após uma denúncia de possível agitação subversiva no estado, o comandante do III Exército declarou que a ordem legal seria mantida a todo o custo.

Cedendo às pressões, o governo propôs aos ruralistas uma comissão técnica mista que avaliasse os problemas da questão agrária. A FARSUL concordou e a Comissão foi instalada com a participação tanto do Governador quanto do Presidente da entidade. No entanto o governo queria um trabalho objetivo. A FARSUL, por seu lado, pretendia prolongar as discussões para evitar ações. A FARSUL e o governo estabeleceram suas intenções e propostas, entretanto, o acordo não aconteceu. Uma nota do governo solicitando aos proprietários que tivessem intenção de colaborar no plano de reforma agrária irritou os dirigentes da entidade máxima dos ruralistas, que voltou a formular pesadas críticas ao governo.

Em meio a esta série de debates, foi fundada a Frente Agrária Gaúcha, uma organização católica que definia por objetivo levar os fiéis a participar da associação e da vida sindical rural, dentro dos princípios católicos.

\section{As Posições Políticas Radicalizam-se}

No mesmo momento destas discussões, o governo do Rio Grande do Sul decretou a encampação da Companhia Telefônica, subsidiária da Internatinal Telegraph and Telephone (IT'T), a fim de estabelecer uma estatal de telecomunicações. A empresa multinacional recorreu da decisão e a disputa se prolongou. $\mathrm{O}$ ato, porém, teve base legal e foi realizado a partir de estudo de uma comissão especial. O governador, então, recusou-se a negociar e estabeleceu a indenização indicada pela comissão, considerada insuficiente pela Companhia, que reconhecidamente não prestava bons serviços e não investia no estado. Brizola, diante de algumas críticas, afirmou que não se tratava de hostilidade aos EUA, mas de defesa dos interesses do estado. A Companhia Rio-Grandense de Telefonia (CRT) consolidava-se, afinal. 
Campanha da Legalidade, Luta de Classes e Golpe de Estado...

A atitude de Brizola influenciou na consolidação da estatização das telecomunicações em nível nacional, em 1962.

No inicio de abril de 1962, firmou-se no Rio Grande do Sul a Ação Democrática Popular, composta por PSD, UDN, PDC, PL e PRP, a fim de disputar a sucessão estadual. Rapidamente definiu-se o nome de Ildo Menegheti como candidato ao governo do estado com mais condições de enfrentar os trabalhistas.

Coincidência ou não, conforme notícia do Correio do Povo, de 23 de março de 1962, o IPES é fundado no estado no dia anterior, em solenidade no Palácio do Comércio, em Porto Alegre. Em meio a esta efervescência social que vivia o estado, o IPES passou a ser propagandeado como uma entidade plural que defendia a revisão integral dos padrões sociais vigentes, defensor das tradições democráticas, cristãs e ocidentais. Seus organizadores admitiam, no entanto, que o Instituto visava à participação efetiva dos democratas autênticos na vida política econômica e social do País. Admitiam que a criação do Instituto era uma articulação anterior de homens do comércio que acreditavam nas reformas dentro da democracia. Como já é de conhecimento publico através da historiografia, o IPES é, junto com o IBAD, o grande organizador da conspiração contra Goulart e a democracia no Brasil (DREIFUSS, 1987). O primeiro presidente do IPESUL foi Álvaro Coelho Borges, o qual, em seu discurso de posse, declarou que a organização era uma necessidade e aspiração de empresários, profissionais liberais e democratas, na convicção da necessidade de estudos e ações para "[...] melhorar a vida do povo sem exigir a perda da liberdade" (Correio do Povo, $1^{\circ}$ de abril de 1962).

Em maio de 1962, o Deputado do PL Paulo Brossard pronunciou mais um virulento discurso atacando Brizola, sob a acusação de promover a desordem e a subversão. Considerando que Dreifuss aponta Brossard como um dos principais contatos do IPES no Rio Grande do Sul e um dos políticos favoritos do grupo para ascender à liderança da sua fração política, não é de estranhar que sua ação seja mais agressiva logo após a fundação do IPESUL. Segundo o referido autor, nos arquivos do IPES encontram-se registros de contatos com Brossard para intensificar os ataques contra Brizola em 1962, em função das eleições próximas e da necessidade de vencer os trabalhistas. 
Nesse mês, Brizola arrecadou mais oposições contra si ao se posicionar contra a Aliança para o Progresso, afirmando que se não fossem feitas as reformas necessárias, haveria uma revolução no Brasil. Matéria publicada pelo O Globo e reproduzida pelo Correio do Povo chamou Brizola de maior fabricador de crises do Brasil, além dos conceitos tradicionais: agitador e promotor da subversão. Também não era coincidência que um grupo de estudos da Escola Superior de Guerra tenha realizado uma pesquisa no Rio Grande do Sul para conhecer seus problemas, também em maio de 1962. Enquanto isso, a FARSUL começava a promover uma campanha de associativismo rural.

O IPESUL, em junho de 1962, conforme o Correio do Povo, promoveu uma série de atividades e palestras expondo suas finalidades e seus objetivos. No programa estavam o Rotary Club, os Círculos Operários de Porto Alegre e os Centros Industriais, por exemplo, além de uma série de sindicatos e organizações sociais.

Quando Goulart também decidiu encampar as lutas pelas reformas, atraiu contra si as fortes oposições e acusações que eram direcionadas a Brizola. Certo é que as mobilizações de agricultores sem-terra não cessaram após o governo de Leonel Brizola, mas não contaram com o apoio do governo de Ildo Menegheti, eleito com amplo apoio dos ruralistas.

Jango, ao passar do discurso para a ação, também começava cada vez mais a ser chamado de demagógico e insuflador da agitação e da subversão. As propostas de reforma agrária, constantemente rejeitadas pelo Congresso, que não aceitava negociar, reduziram as possibilidades de diálogo. A criação da Superintendência da Reforma Agrária (SUPRA) foi vista com muita apreensão por ruralistas e conservadores. As propostas de distribuição de terras, e o decreto que desapropriava as terras às margens das rodovias, ferrovias e açudes foram acusadas de verdadeiros atentados à propriedade privada.

Ildo Meneghetti, então governador do estado, não perdeu a oportunidade de sair em ataque ao governo afirmando que no estado ele iria garantir o direito à propriedade privada, não admitindo "invasões de terras ou violência" (Correio do Povo, março de 1964). Noticias que tinham por objetivo criar tensão e sensacionalismo eram frequentemente divulgadas, como as que constantemente afirmavam 
Campanha da Legalidade, Luta de Classes e Golpe de Estado...

haver pregação ou agitação subversiva no interior ou a que afirmava que $42 \%$ das terras no Rio Grande do Sul seriam consideradas de utilidade pública.

Tais episódios tinham o objetivo de mostrar os interesses sociais e as organizações sociopolíticas que estavam disputando a sociedade naquela conjuntura. Os debates e os problemas referentes às reformas sociais perduraram até 1964. A mobilização urbana e rural foi consecutivamente denunciada como nociva à nação e à produção.

Porém, a radicalização do momento político e o avanço das demandas sociais por reformas de base fizeram com que os setores conservadores se afastassem cada vez mais do Presidente, e não o contrário. O comício da Central do Brasil, em 13 de março de 1964, marcou a atitude de Goulart de aceitar este afastamento, voltando-se para os únicos que ainda poderiam apoiá-lo: as esquerdas.

Contando com a participação do comando Geral dos Trabalhadores (CGT) da UNE, do PTB e do PSD agressivo, o comício foi um marco. Para piorar, os ministros militares estavam no palanque e o esquema de segurança foi de responsabilidade do Ministro da Guerra. Os medos de todos os conservadores estavam se realizando, a possibilidade da união de setores amplos da esquerda com apoio militar. Por esse motivo, também, a rebelião de sargentos e de marinheiros foi tão atacada como anarquia e subversão.

$\mathrm{Na}$ abertura da sessão legislativa de 1964, Jango já havia enviado mensagem ao Congresso solicitando e recomendando a aprovação das reformas de base. A partir de então, as disputas políticas acirraram-se mais ainda. Os proprietários rurais e empresariais gaúchos lançaram manifestos nos jornais protestando contra "a demagogia, a agitação, a intranqüilidade e a subversão". Organizou-se no um "movimento nacional feminino em defesa do regime". O Correio do Povo, em editorial, passou a acusar Goulart e os líderes de esquerda de um "neoperonocastrismo", expressando seus temores em relação aos líderes Juan Domingues Perón e Fidel Castro. Ampliavam-se os discursos sobre as ameaças de "república sindicalista” ou de aumento da caminhada para a bolchevização do País.

Ildo Meneghetti afirmou, em mensagem ao Congresso Nacional, que o Rio Grande do Sul reagiria a qualquer atentado contra a 
Constituição, invocando as mesmas denúncias de agitação e subversão, recebendo por isso homenagens e solidariedade dos representantes das classes proprietárias, corporificadas nas federações das Indústrias e do Comércio do Rio Grande do Sul. Neste momento, a alteração no campo semântico já fora operada. Agora a defesa do regime estava na necessidade de evitar o avanço da subversão, e no limite, na deposição do Presidente.

O movimento feminino referido anteriormente foi fundado em 20 de março de 1964, em Porto Alegre, sob o nome de Ação Democrática Feminina (ADF), e tinha como coordenadora geral Ecilda Haensel. No ato de instalação, na Pontifícia Universidade Católica do Rio Grande do Sul (PUCRS), foi eleita a diretoria presidida por Ilda Malmhardt, sendo definida como organização cívica em defesa da democracia e dos valores cristãos.

A ADP, que se consolidou como frente política no estado, principalmente após a vitória de Meneghetti ao governo, divulgou um manifesto, em março de 1964, conclamando ao "estado de alerta para evitar o golpe", que viria de Goulart e das esquerdas. Este discurso se consolidaria daquele momento em diante.

Em contraposição, em 19 de março, foi realizada uma reunião com amplos setores das forças de esquerda no apartamento do agora deputado Leonel Brizola ${ }^{8}$, no Rio de Janeiro, quando participaram, além do ex-governador gaúcho, o Governador de Pernambuco, Miguel Arraes, e os deputados Paulo de Tarso, Almino Afonso, entre outros. $\mathrm{Na}$ avaliação do encontro, que durou a noite inteira, a situação nacional extremamente delicada, levando em conta as mesmas condições que justificaram o Golpe de Estado de 1937, de que Goulart poderia valer-se no momento, por este motivo definiu a defesa das liberdades democráticas como o ponto fundamental do seu programa. O equilíbrio de forças exigiria saídas para o impasse do regime político, com a realização de um plebiscito junto à população para a execução das reformas de base. A ideia de Constituinte defendida por Brizola, inclusive no Comício da Central do Brasil, foi rejeitada pelo conjunto das forças presentes (Correio do Povo, 20 de março de 1964). Seu programa incluiu a colaboração com o CGT e a consecução de uma Frente Popular de apoio às reformas e à reivindicação junto ao Presidente de um ministério nacionalista que as executasse. 
Campanha da Legalidade, Luta de Classes e Golpe de Estado...

Tal manifestação poderia soar apenas como discurso se não fosse a prática política destes setores em incentivar a organização das classes trabalhadoras. Tal reunião mostra a inconsistência das teses que afirmam que o conjunto das esquerdas defendia o golpe e o fechamento do Congresso. Até mesmo a proposta de Constituinte, que não é a mesma coisa que fechamento do Congresso, foi rejeitada.

A partir de então, as posições polarizaram-se ainda mais. No Rio Grande do Sul, os servidores federais iniciaram um movimento, capitaneado pela Federação dos Servidores Públicos Federais do Rio Grande do Sul, apoiando a paridade entre servidores civis e militares e as reformas de base. Dezenas de prefeitos do estado, da mesma forma, enviaram mensagem de apoio às medidas do Presidente e às ações no sentido das reformas.

Por outro lado, em editorial, o Correio do Povo atacou virulentamente o CGT, tido como superpoderoso que estaria ditando os rumos do poder, enquanto o jornalista Arlindo Pasqualini destilava ódio a Jango, chamando-o de demagogo, corrupto e inepto.

As forças conservadoras, capitaneadas pela ADP, passaram a pregar no Rio Grande do Sul constantemente "[...] a união de todos os democratas para salvar a democracia" da demagogia e da subversão. As criticas ao governo e a paralisia decisória e das atividades produtivas pelo clima de agitação política eram constantes, partindo das organizações das "classes produtoras", principalmente a FIERGS e a Federação do Comércio. Qualquer crítica a partidos ou ao Congresso e a deputados era acusada de atentado às instituições, instalando um clima de polarização franca e de denuncismo que, nas fontes, sugere uma verdadeira histeria. As mulheres reunidas na ADF clamavam pelo apoio do clero, a fim de ampliar sua participação e influência, para realizar sua "campanha cívica de defesa da democracia". Uma das suas primeiras ações foi convocar pelos jornais a Marcha da Família, com Deus, pela Liberdade para o dia 7 de abril, às 16 horas, no largo da prefeitura de Porto Alegre. Na esteira da marcha realizada em São Paulo e em oposição ao comício das reformas da Central e aos que se programavam fazer no interior do País, incluindo a capital, as mulheres conservadoras da classe média saíam na frente para forçar a derrubada do governo. 
O governo do Estado, em meio ao acirramento político, decidiu proibir a greve dos professores por aumento salarial, mostrando assim sua "vocação democrática" e aproveitando o clima para acusar a parede de subversiva, rótulo que passou a ser usado a qualquer reivindicação por direitos sociais ou políticos. Os ruralistas, neste contexto, já afirmavam que iriam defender as terras e a propriedade a "qualquer preço". Afere-se desta afirmação todas as suas conclusões necessárias. Liderados por Meneghetti e Carlos Lacerda, os governadores dos partidos conservadores pareciam conspirar abertamente. Meneghetti, Lacerda, Adhemar de Barros (Governador de São Paulo) e Magalhães Pinto (Governador de Minas Gerais) realizavam sucessivas reuniões e lançavam manifestos sempre apontando a necessidade de união das "forças democráticas" contra a subversão, sempre afirmando que Goulart poderia não presidir a eleição de 1965.

$\mathrm{Na}$ tentativa de apoiar Goulart, o CGT lançou um manifesto afirmando que deflagraria greve geral, caso fosse pedido o impeachment do Presidente, em função dos sucessivos ataques conservadores. Exigia a aprovação das reformas de base pelo Congresso e a anistia aos envolvidos no levante dos sargentos. Clamava, por fim, pela união dos trabalhadores na difícil conjuntura de crise política (Correio do Povo, 21 de março de 1964). O manifesto, porém, parece ter surtido o efeito contrário, tornando os adversários ainda mais preocupados ou mais convencidos dos argumentos sobre o poder sindical. No final de março, o manifesto dos generais já deixava claro o discurso dos golpistas e a disposição de depor Goulart. No Rio Grande do Sul, um Movimento Democrático Universitário, lançou um manifesto enumerando as críticas às altas autoridades que estariam "financiando a subversão", conclamando os "estudantes a se unir e participar de todos os atos públicos em defesa da democracia".

Boatos alarmistas eram difundidos a fim de incutir medo e pânico na população, além de aumentar ainda mais o clima de insegurança, como em Porto Alegre, quando circulou, nos últimos dias de março, a notícia de que o governo iria federalizar as polícias estaduais. Embora constantemente negados pelas autoridades, eles se perpetuavam e a tensão aumentava. Na esteira denuncista, o deputado estadual Luciano Machado, do PSD, afirmou que a situação 
Campanha da Legalidade, Luta de Classes e Golpe de Estado...

nacional chegava ao seu ponto mais crítico, conclamando: “[...] ou reagiremos ou seremos tragados pelos comunistas, hoje em nossa pátria, chefiados pessoalmente pelo Presidente da República [...] o golpe as instituições é iminente. [...] confio no patriotismo de nossas forças armadas". Este discurso sintetizava os argumentos que justificariam o golpe. Os comunistas chefiados pelo Presidente dariam o golpe contra as instituições e as Forças Armadas patriotas poderiam defender a Constituição. Encerrava o deputado avisando aos "rio-grandenses democratas" que estava na hora de se organizar, armar-se e preparar objetivamente para a luta.

A percepção geral era que se vivia uma situação pré-revolucionária em função do clima de radicalização política de ambos os lados. A movimentação militar era intensa, demonstrando que algo diferente estava no ar. A sublevação dos marinheiros foi a gota d'água para os golpistas precipitarem suas ações. A anistia dada aos militares por Jango foi considerada o caminho para a subversão, pois nenhum oficial poderia mais confiar em seus subordinados, sendo que, segundo estes, o espírito dos assassinos comunistas de 1935 era conclamado direta e indiretamente. O manifesto da LDF no Rio Grande do Sul dava ênfase a pedido de paz e ordem atacando duramente ao Presidente.

\section{O Golpe de 1964 e a Tentativa de Resistência no Rio Grande do Sul}

Em $1^{\circ}$ de abril noticiava-se a deflagração do movimento golpista, com tropas partindo de Minas Gerais, sob o comando do General Mourão Filho, com apoio do Governador Magalhães Pinto. De imediato, o comandante do II Exército, Amauri Kruel, aderiu à revolta. Na justificativa desses, o Golpe dava-se pela preservação da liberdade e da democracia, contra a conspiração comunista. Os acontecimentos já são bastante narrados e conhecidos.

Face ao movimento golpista, Goulart nomeou o general legalista Ladário Pereira Telles para assumir o comando o III Exército, que chegou a Porto Alegre nas primeiras horas do dia $1^{\circ}$ de abril, 
onde foi recepcionado pelo Prefeito de Porto Alegre Sereno Chaise (PTB), no mesmo momento em que o General Jair Riberio, recémoperado, reassumiu o Ministério da Guerra. Ao chegar, o General lançou uma proclamação concitando o III Exército a permanecer fiel à legalidade e ao mandato constitucional do Presidente João Goulart, junto ao povo e à resistência civil. O governo, no entanto, acreditava ter a situação sob controle, afirmando que iria reprimir a rebelião, confiando igualmente no espírito legalista das Forças Armadas e no democrático do povo.

O governador do estado, Ildo Meneghetti, tomou uma série de medidas a fim de hipotecar apoio aos golpistas. Solicitou de imediato, por decreto, as emissoras de rádio e televisão sediadas na capital. Sua justificativa era "[...] evitar a sua utilização para a difusão de pronunciamentos que possam, de qualquer modo, perturbar a tranqüilidade reinante". Afirmou também que, diante da crise, manteria a ordem em todo o Rio Grande do Sul.

O objetivo era muito claro, evitar que a Cadeia da Legalidade, organizada por Brizola ante a tentativa de Golpe de 1961 fosse repetida, tratando-se, na prática, de censura e do controle estatal, a fim de impedir a reação das forças contrárias ao Golpe no estado. No plano militar, o Governo colocou a Policia Militar e a Polícia Civil de prontidão. A guarnição da sede do governo foi reforçada e a área adjacente ao Palácio Piratini foi interditada ao trânsito. Setores do governo adotaram medidas a fim de colocar os veículos em prontidão na necessidade de utilizá-los para deslocar tropas.

A sede do governo foi novamente transformada em quartel general, protegido por barricadas, só que, desta vez, a favor do Golpe e contra a ordem constitucional, embora o discurso dos sediciosos dissesse o contrário. Não deixa de saltar aos olhos que mesmo o governo afirmando que as medidas eram apenas preventivas e reinasse a calma no estado, tais medidas visavam à repressão rápida dos focos de resistência. O III Exército também entrou em prontidão. Da mesma forma, a $5^{\text {a }}$ Zona Aérea.

Chama atenção a tomada de posição do Correio do Povo. Em manifesto, com um tom de dramaticidade latente, denominada Pela lei e pela ordem, o jornal posicionava-se. A firmou que, frente aos "graves acontecimentos de caráter político militar”, deveria se manifestar ao 
Campanha da Legalidade, Luta de Classes e Golpe de Estado...

lado da "defesa das instituições democráticas e da ordem constitucional", compadecendo-se com "atentados a própria dignidade das forças armadas e à própria autenticidade do regime, pela inversão da hierarquia e pela quebra de disciplina". Clamava ainda, pelas Forças Armadas para cumprir sua "histórica missão", de serem "sustentáculos da lei e da ordem", sob o espírito de sua vocação histórica em defesa do cristianismo e do democratismo-liberal. O encerramento não poderia ser mais categórico: “[...] o caminho a seguir nesta hora de decisão não comporta dúvidas ou vacilações: é o do saneamento ético das cúpulas políticas e administrativas e da anulação dos inimigos da pátria e da democracia".

Está presente nesse manifesto boa parte do discurso golpista, tornando necessário infringir a Constituição "pelo seu próprio bem e pela manutenção da ordem”. Tal movimento revela que a ação teve, assim como sempre teve historicamente, o fundo político. A legalidade deveria estar a serviço daqueles que realmente poderiam ter o poder de decidir o que é a "verdadeira ordem constitucional". Também põe por terra o argumento de suposta neutralidade desse setor da imprensa.

Quando percebia que sua manobra de requisitar as emissoras de telecomunicações falhava, pois elas eram ocupadas por tropas do III Exército leais a Goulart, que ainda se encontrava com pouca base social e política em Porto Alegre, ainda em $1^{\circ}$ de abril, por volta das $11 \mathrm{~h} 30 \mathrm{~min}$, o governador Ildo Meneghetti declarou-se aliado das forças sediciosas. Contra Goulart, transferiu a sede do Governo para Passo Fundo, no $3^{\circ}$ batalhão de Caçadores da Brigada Militar, lançando mais um manifesto na batalha de opinião pública. Nas constantes manobras do campo semântico, ele se declarou na resistência contra os inimigos da democracia, conclamando pela organização do povo gaúcho contra Goulart.

A situação do Governador iria se agravar ainda mais. Ao entrar em contato com o então comandante do III Exército, General Galhardo, soube que este estava disposto a apoiar o movimento golpista e anunciou que o Presidente já havia nomeado o General Ladário Pereira Telles para substituí-lo no comando, mas afirmou a disposição de prender este general quando se apresentasse. No 
entanto, o general Ladário Telles foi confirmado e assumiu efetivamente o comando do III Exército com o apoio de seu comando.

Este, por sua vez, ocupou as emissoras de rádio, com tropas fiéis à legalidade, dando oportunidade para que as forças civis de apoio a João Goulart dessem início ao processo de levante popular, sob a liderança de Leonel Brizola e Sereno Chaise, tentando repetir a Campanha da Legalidade de 1961. Um grande número de populares marchou para a Praça da Matriz, a fim de depor o governador e entregar o governo a Leonel Brizola. O clima no Palácio Piratini era de extrema tensão. A tropa de choque da Brigada Militar foi acionada e tomou posição defensiva. O impasse foi atenuado quando o Prefeito Sereno Chaise convocou a população que se aglomerava para acompanhar com ele o desenrolar dos acontecimentos no Paço Municipal.

Ainda na manhã do dia primeiro, o cerco contra o governador estava se fechando. O governo, entretanto, encontrou uma brecha legal para negar o pedido do General Ladário Telles de requisição da Brigada Militar, uma vez que esta poderia ser feita através de decreto do Presidente, que já não tinha condições políticas de fazê-lo. O novo comandante do III Exército ainda tentou, sob uma proclamação à Brigada Militar, convocar os soldados leais à legalidade a lutar ao lado das tropas leias a Goulart, apelando para o espírito legalista da corporação. No entanto, tal apelo não pareceu surtir muito efeito. A situação complicara-se, pois o comando do general não era plenamente reconhecido, sendo que parte das tropas sediadas em Santa Maria, Alegrete e Uruguaiana não obedeciam ao novo comando, estando, também, sublevadas.

As forças civis partidárias de João Goulart articularam-se, enquanto isso, em torno do Palácio da Prefeitura Municipal, destacava-se a liderança do Prefeito Sereno Chaise. De posse das rádios gaúchas, a Cadeia da Legalidade foi reeditada, divulgando notas e proclamações de entidades, conclamando o povo à resistência contra o golpe dos gorilas. O movimento culminou com a realização de um comício no Largo da Prefeitura que contou com oradores como Leonel Brizola, Álvaro Ayala, Vilson Vargas, Floriano D’ávilla e o próprio Sereno Chaise. Todos pediram a união das forças populares contra o golpe às instituições e a defesa da Constituição. 
Campanha da Legalidade, Luta de Classes e Golpe de Estado...

Segundo o Correio do Povo, o prefeito Sereno Chaise permaneceu em seu gabinete desde o início da crise, atento ao desenrolar dos acontecimentos, cercado por seus auxiliares e por "elevado número de populares", que se colocaram em frente ao prédio da prefeitura. Desde então, o Prefeito recebeu manifestações de apoio e solidariedade de inúmeras organizações e entidades: Comando de Reivindicações dos Servidores do Estado, Comando Nacionalista de Guarujá, Frente Nacionalista do Magistério Gaúcho, Conselho Sindical Feminino, Comando dos Servidores Federais do Rio Grande do Sul, Comissão dos Profissionais Liberais, Sindicato dos Empregados no Comércio Hoteleiro e Similares de Porto Alegre, funcionários da Prefeitura Metropolitana, do MASTER, Sindicato dos Oficiais de Barbeiros e Similares, da Associação dos funcionários da CEEE, do Sindicato dos Trabalhadores de Energia Elétrica em Porto Alegre, e "[...] mais de uma dezena de outras entidades de classe, levaram ao chefe do executivo porto-alegrense, estendendo-a ao presidente da república, sua solidariedade".

A União Estadual dos Estudantes divulgou nota, ainda no dia primeiro, manifestando seu apoio à manutenção da democracia, pela garantia dos direitos constitucionais, e contra o golpe, conclamando pela realização das reformas de base. Por sua vez, a denominada, embora desconhecida, Mocidade Livre e Democrática do Rio Grande do Sul lançou manifesto apoiando o Golpe, apoiado nos mesmos discursos brandidos pelos sediciosos. A sociedade estava dividida.

Por sua vez, os titulares dos órgãos federais no Rio Grande do Sul, sediados na capital, reunidos em assembleia deliberaram criar uma força de vanguarda subordinada ao III Exército, com o objetivo de participar da luta em defesa das instituições democráticas. $\mathrm{Na}$ mesma ocasião, foi lançado um manifesto assinado por 50 titulares dos órgãos federais manifestando apoio e confiança no Presidente João Goulart e aos poderes constituídos. Importantes debates foram travados na Assembleia Legislativa do Estado, mas nenhuma resolução foi aprovada, a despeito dos esforços dos deputados trabalhistas em tentar aprovar uma moção de apoio ao Presidente, o mesmo aconteceu na Câmara de Vereadores de Porto Alegre. As forças políticas também estavam divididas. 
Já em 2 de abril, diante da notícia de que Goulart abandonara Brasília, anunciava-se a vitória do movimento rebelde. As 3 horas e 15 minutos de 2 de abril, o Presidente João Goulart desembarcava no aeroporto Salgado Filho, em Porto Alegre, acompanhado por ministros e auxiliares, junto com o General Assis Brasil. Cerca de duzentas pessoas esperavam Jango, recepcionado com "vivas ao Presidente do Brasil". Depois de ser cumprimentado pelo comandante do III Exército, Ladário Pereira Telles, pelo Prefeito de Porto Alegre, Sereno Chaise e pelo Deputado Leonel Brizola, bem como por diversos deputados estaduais, João Goulart foi escoltado por vários tanques e por elementos da companhia de guarda, até a residência do comandante do III Exército. Um dos oficiais que acompanhavam o Presidente afirmou que ele vinha para o Rio Grande do Sul dar prosseguimento à luta pela retomada do poder (Correio do Povo, 2 de abril de 1964). De fato, o estado foi o líder do movimento que garantiu sua posse em 1961, e era sua maior esperança de contar com base social e militar para deflagrar uma resistência efetiva.

Entretanto, a situação militar no III Exército estava ficando cada vez mais desfavorável. Em 1961, a unidade do III Exército foi fundamental para a resistência ao golpe, e os lideres da resistência em 1964, incluindo o Presidente, sabiam disso. Por isso fizeram o possível para manter o controle desse Exército. Mesmo que o quartel general anunciasse que exercia controle sobre todo o território do Rio Grande do Sul, os jornais indicavam que as tropas da Divisão de Cavalaria, com sede em Uruguaiana, a $3^{a}$ Divisão de Cavalaria, com sede em Bagé e a $3^{a}$ Divisão de Infantaria, com sede em Santa Maria, não recebiam ordens do III Exército, estando sublevadas. O General, Newton Barra que viajou para assumir o comando em Santa Maria, não conseguiu fazê-lo, tendo que retornar a Porto Alegre.

Mais preocupante ainda, foi que a $5^{a}$ Região Militar que controlava o Exército no estado do Paraná, subordinada ao III Exército, comandado pelo General Dario Coelho, também se sublevou, declarando apoio e adesão ao movimento golpista $\mathrm{O}$ general Cristiano Figueiredo, que deveria assumir o comando da $5^{a}$ Região Militar, não obteve êxito. As tropas sediadas em Santa Catarina aderiram ao comando do $5^{\circ}$ Distrito Naval, que aderiu ao levante. A notícia acalentadora era que a $5^{\text {a }}$ Zona Aérea, comandada pelo Brigadeiro 
Campanha da Legalidade, Luta de Classes e Golpe de Estado...

Othelo Ferraz, declarou-se fiel ao III Exército e à Constituição. A Brigada Militar, que em 1961 também foi importante para a resistência, manteve-se fiel ao Governador Meneghetti, e não aceitou nem a requisição da tropa feita pelo General Telles nem o apelo feito pelo mesmo a fim de que se unissem à resistência pela legalidade.

Mesmo com uma forte mobilização popular e com o controle de praticamente todo o Rio Grande do Sul, o Presidente Goulart achou que não teria condições de resistir ao Golpe com as condições militares que dispunha. Recusou-se, por sua vez, a distribuir armas à população que estava disposta a resistir, como fizera Brizola em 1961. E, às 11 h45min, do dia 2 de abril, voou de Porto Alegre para o exílio, segundo os jornais, acompanhado por auxiliares e militares, agradecendo a lealdade do povo gaúcho e das forças do III Exército, como baluartes na defesa da legalidade e da democracia.

Faz-se mister narrar estes acontecimentos a fim de esclarecer e problematizar uma tese que a muito frequenta a historiografia brasileira. A versão corrente, criada ainda durante a Ditadura, dá a entender que não houve resistência ao Golpe. Este foi um consenso nacional, portanto, a fim de salvar a democracia dos comunistas, das esquerdas, da demagogia e da corrupção. Como em muitos outros elementos tomados como explicativos do Golpe, a versão dos sediciosos se assentou como verdade histórica. Por outro lado, mostra que as versões que tomam como explicativos da totalidade, os casos de Rio de Janeiro e São Paulo, não são suficientes. A sorte da limitada democracia brasileira foi decidida no Rio Grande do Sul, onde a resistência depositou suas últimas esperanças. As chances de vitória eram reais.

Mesmo sendo anunciada a vitória do Golpe e os sediciosos iniciando as ações de limpeza, ainda durante os dias 3 e 4 de abril, movimentos contrários aos golpistas e ao governo foram tentados no estado, mas como amostra do que viria a seguir, foram duramente reprimidos pela Brigada Militar. Com a situação em segurança, o Governador Meneghetti voltou para Porto Alegre junto com o novo comandante nomeado para o III Exército, o General Poppe de Figueiredo. Os apoiadores e partidários de Meneghetti então começaram a aparecer e foi organizada a "festa da vitória da democracia”, consubstanciada num comício realizado pelo governador 
e pelas autoridades militares. O Arcebispo de Porto Alegre, Dom Vicente Scherer, a maioria da imprensa e as entidades das "Classes Produtoras" manifestaram apoio em face da vitória e o desejo da reorganização e "limpeza" da nação.

Imediatamente após o Golpe, a nova fase política que marcaria o Brasil começava a tomar contornos. Centenas de pessoas foram presas, inclusive o Prefeito de Porto Alegre, Sereno Chaise, mesmo sob veementes protestos de vereadores e deputados. Leonel Brizola teve de fugir e se esconder. Ministros de Goulart, lideranças de esquerda e opositores do Golpe foram presos. Goulart, depois de tentar se exilar em território nacional, como fizera Vargas em 1945, numa de suas fazendas, teve de rumar para o exílio no Uruguai. A região do Rio dos Sinos foi colocada sobre intervenção militar, com várias pessoas presas a fim de evitar desordens. Em nível nacional e estadual, teve inicio o período de acusações, expurgos e perseguições políticas. O clima de triunfalismo dos golpistas era evidente. O Brasil emergia, assim, em mais de vinte anos de arbítrio e de Terrorismo de Estado, iniciava a Ditadura Civil-Militar, sob os louros e louvores de uma nova democracia.

Por fim, é importante salientar, conforme demonstrou amplamente Carlos Fico (2008) ${ }^{10}$, o Golpe contou com total apoio e colaboração do Governo dos Estados Unidos, através do embaixador Lincoln Gordon. Tal apoio era não somente político, mas também militar consubstanciado num plano de contingência que previa apoio logístico e de tropas para os golpistas brasileiros, expresso na famosa Operação Brother Sam que se sabe hoje fazia parte de um plano muito mais amplo para apoiar a sedição no Brasil. Tal plano, contou com planejamento conjunto entre militares brasileiros e o governo dos EUA. Sabe-se também a ampla participação desta potência estrangeira na campanha de desestabilização e na conspiração contra Goulart, junto com as entidades das classes conservadoras do Brasil. Compreender este ponto é fundamental para entender a relação entre o Golpe no Brasil e o contexto mais amplo da Guerra Fria, onde tal conflito se situa. Além do mais, ajuda a entender como numa sociedade dividida o golpe obteve êxito, pois a resistência ao golpe não foi pequena. Entretanto, a coesão de grande parte dos militares, sob o signo da Doutrina de Segurança Nacional e do anticomunismo, foi 
fundamental para o êxito da sedição. Sabe-se também o papel dos Estados Unidos na formulação da Doutrina de Segurança Nacional e na formação da ESG responsável pela doutrina no Brasil, bem como do financiamento da difusão destas ideias e nas organizações anticomunistas e anti-Goulart. Não se trata de pensar numa grande conspiração internacional, mas compreender o processo histórico em sua totalidade, para não falsear a realidade ou isolar elementos importantes e complementares para entender como o Brasil mergulhou em mais de vinte anos de Ditadura de Segurança Nacional.

Assim, não se sustentam as avaliações que se referem à falta de apreço pela democracia pelas esquerdas e pelo governo de João Goulart. Na verdade, o Brasil tinha em 1964 dois projetos distintos de democracia. Um queria sua ampliação, mesmo que dentro de certos limites, pois como ficaram demonstradas nas fontes, as esquerdas acusadas de golpistas não reivindicavam o Golpe, pelo contrário, temiam-no. A outra, vencedora, reivindicava sua limitação.

O Golpe pode ser entendido como a culminância de um amplo movimento civil-militar contra um projeto de sociedade que pretendia promover mudanças dentro de preceitos nacionalistas. Movimento que foi engendrado dentro de um processo de luta de classes contra o qual as classes dominantes impuseram seu projeto contrário e pela força.

\section{Campaign of the Legality and Coup d'Etat in the Rio Grande do Sul (1961-1964)}

Abstract: The historical process of construction of the Civilian-Military coup d'Etat, victorious in 1964, had in the Campaign of the Legality a singular moment. 1964 were preceded of deep polarization politics between the sectors conservatives and progressive. It was in the Rio Grande do Sul that the resistance of the forces constitutional to the coup d'Etat attempt initiated, in 1961. This first coup-minded attempt was, however, frustrated for the popular mobilization, directed from Porto Alegre. Situation that will not be happened again in 1964, when the resistance for the Legality had new attempt. To understand this process in a ampler and complex dimension is the objective of this article.

Keywords: Brazil. Campaign of the Legality. Civilian-Military Coup d'Etat of 1964. Rio Grande do Sul. 


\section{Diorge Alceno Konrad e Rafael Fantinel Lameira}

\section{Notas}

${ }^{1}$ Este artigo contém partes modificadas e atualizadas do projeto de pesquisa "Estado, Movimentos Sócio-Políticos e Golpe Civil-Militar - Rio Grande do Sul (1954-1964)", com recursos provenientes do Probic/FAPERGS, cujo relatório final foi apresentado em 2008.

${ }^{2}$ Bevilacqua teve atuação destacada na defesa da legalidade, e por isso foi indicado ao comando geral da $3^{\text {a }}$ Região Militar.

${ }^{3}$ Frequentemente era utilizada pelos seus próprios membros e pelos setores hegemônicos da imprensa escrita, a noção de classes produtoras, para designar ruralistas, empresários, comerciantes, financistas ou todos os indivíduos ou grupos proprietários.

${ }^{4}$ RODEGHERO, Carla. O diabo é vermelho. Imaginário anticomunista e Igreja Católica no Rio Grande do Sul (1954-1964). Passo Fundo: EDIUPF, 1998,

${ }^{5}$ Para mais informações sobre o MAC e a campanha anticomunista ver o trabalho de MOTTA, Rodrigo Patto Sá. Em guarda contra o "perigo vermelho". O anticomunismo no Brasil (1917-1964). São Paulo: Perspectiva/FAPESP, 2002.

${ }^{6}$ Sobre este processo, ver DREIFUSS, René Armand. 1964: a conquista do Estado. Ação política, poder e golpe de classe. 5 ed. Petrópolis: Vozes, 1987.

${ }^{7}$ Seu governo iniciara em 25 de março de 1963, em substituição a Leonel Brizola. ${ }^{8}$ Após a Campanha da Legalidade e seu governo no Rio Grande do Sul, a popularidade de Brizola se tornou tão intensa em nível nacional que, em abril de 1962, cento e vinte dirigentes sindicais vieram ao Rio Grande do Sul convidar Brizola para ser candidato a deputado federal pela Guanabara.

${ }_{9}$ Todas as referências a seguir são relacionadas ao Correio do Povo, entre $1^{\circ}$ e 5 de abril de 1964.

${ }^{10}$ O grande irmão: da Operação Brother Sam aos anos de chumbo. O Governo dos Estados Unidos e a Ditadura Militar Brasileira. Rio de Janeiro: Civilização Brasileira, 2008.

\section{Referências}

Correio do Povo. Porto Alegre, $1^{\circ}$ de abril de 1964.

Correio do Povo. Porto Alegre, 2 de abril de 1964.

Correio do Povo. Porto Alegre, 3 de abril de 1964.

Correio do Povo. Porto Alegre, 4 de abril de 1964.

Correio do Povo. Porto Alegre, 5 de abril de 1964.

DREIFUSS, René Armand. 1964: a conquista do Estado. Ação política, poder e golpe de classe. 5 ed. Petrópolis: Vozes, 1987. 
Campanha da Legalidade, Luta de Classes e Golpe de Estado...

FICO, Carlos. O grande irmão: da Operação Brother Sam aos anos de chumbo. O Governo dos Estados Unidos e a Ditadura Militar Brasileira. Rio de Janeiro: Civilização Brasileira, 2008.

MOTTA, Rodrigo Patto Sá. Em guarda contra o "perigo vermelho". O anticomunismo no Brasil (1917-1964). São Paulo: Perspectiva/FAPESP, 2002.

RODEGHERO, Carla. O diabo é vermelho. Imaginário anticomunista e Igreja Católica no Rio Grande do Sul (1954-1964). Passo Fundo: EDIUPF, 1998.

Recebido em 23/09/2011.

Aprovado em 17/01/2012. 